\title{
Advancements in the Field of Neuroscience
}

\author{
Hassaan Tohid* \\ Center for Mind and Brain, University of California, Davis, USA
}

*Corresponding author: Hassaan Tohid, Visiting Neuroscientist, Center for Mind and Brain, University of California, Davis, USA, E-mail: hassaantohid@hotmail.com

Received Date: February 01, 2016 Accepted Date: February 02, $2016 \quad$ Received Date: February 04, 2016

Citation: Tohid, H. Advancements in the Field of Neuroscience. (2016) Int J Neurol Brain Disord 3(1): 11-12.

\section{Introduction}

If there is ever a branch of medical science that defined the course of future remedies, and if there has ever been a period in entire human history which paved the way for potentially innumerable cures in a brief period, it is Neuroscience in the last couple of decades. In the last two to three decades, the field of neuroscience has gone rapid advancement and alterations. Various discoveries have been made, thousands of peer review research articles have been written \& published, and various new concepts have been evolved. Moreover, several Nobel Prizes have been awarded in Neuroscience in the last twenty five years. The ongoing advancement in the field of neuroscience can be estimated by the fact that since the beginning of the Nobel Prize tradition in 1901, in total 29 Nobel Prizes have been awarded in just the field of neuroscience ${ }^{[1]}$.

Some notable discoveries in the past few decades include the discovery of Functional magnetic resonance imaging or functional MRI (fMRI). This technology revolutionized not only the world of neurosciences but the world of medicine as a whole. This is a procedure of functional neuroimaging using MRI technology that observes and records activity of the brain by pointing alterations linked with the flow of blood ${ }^{[2]}$. The fMRI helped modern scientists understand what part of the brain is associated with what kind of function. The area of the brain in use can be easily seen by fMRI showing the high activity due to high blood flow. The patient is asked to lie down with his head inside the scanner and is asked to perform certain tasks. Brain activity during these tasks is recorded by taking images, mostly via Blood oxygenation level dependent (BOLD) imaging. BOLD is aprocedure to create images in functional MRI (fMRI) studies, and is based on the blood flow variations and differences to detect the active and inactive part of the brain. In this technique the flow of blood is controlled as a result of $\mathrm{CO}_{2}$ and $\mathrm{O}_{2}$ tension of the areas of the brain cortex. The procedure runs in a way that the subject (person) lying under the scanner is asked to perform a task, this increases the activity in certain part of the brain of the subject related to the action performed by the subject. This results in a reduction in oxygenated hemoglobin concentration, while increase in local $\mathrm{CO}_{2}$ and augmentation in deoxyhemoglobin, caused by the extraction fraction of $\mathrm{O}_{2}$ from the localized capillaries. As a consequence, in a few seconds cerebral blood flow increases to compensate and provides the deficient $\mathrm{O}_{2}$ while taking away the deoxy hemoglobin ${ }^{[3,4]}$. This particular activity of local tissue oxygenation is recorded as an image and later analyzed.

This technology also helped many neuroscientists justify the concept of mirror neurons which was only believed to be a hypothesis by many scientists for a long time. Technological advancement showed evidences that mirror neurons do exist and these neurons do play an important role in many aspects of brain functionality like imitation as well as empathy ${ }^{[5,6]}$. In addition to imitation and empathy, understanding goals and intentions ${ }^{[7]}$ and Theory of mind ${ }^{[8,9]}$ were also found associated with these unique newly discovered neurons. Later the same concept helped treating the phantom limb pain (a phenomenon in which the patient with amputated limb feels excruciating pain and uncomfortable sensation in the missing limb). Legendry neuroscientist Dr. VS Ramachandran from the University of California, San Diego proposed a new method of treating this phantom pain by the use of a mirror box. The mirror box successfully treated the patients and the patients treated with the mirror box reported feeling better and painless by the use of the 
mirror box. This is just one example of the latest advancements in the field of neuroscience.

The advancement did not come to a halt at the discovery of mirror neurons. Some relatively new advancements include function of single ion channels in cells, discovery of G-protein coupled receptors and their role in signal transduction. Today in the $21^{\text {st }}$ century we have knowledge about the signal transduction in the nervous system involving dopamine, more information on ion channels, concept of odorant receptors and the organization of the olfactory system. Discovery of the machinery regulating vesicle traffic and the prion proteins are worth mentioning. The discovery of prion protein by the renowned scientist Stanley Pruisiner from UCSF was another outstanding achievement in the field ${ }^{[10]}$. The concept of prion proteins helped understand the pathophysiology of many neurological disorders like Creudzfelt Jakob Disease (CJD), kuru, scrapie, and bovine spongiform encephalopathy (BSE) $)^{[11]}$.

Some more new discoveries include Place cells and grid cells (positioning system in the brain). Place cells were discovered by the Norwegian neuroscientist Edvard Ingjald Moser $\&$ his then wife May-Britt Moser in the hippocampus for which the couple was awarded the Nobel Prize in Physiology \& Medicine in 2014. These are a unique kind of neurons that are activated when a subject enters a particular place in his environment known as a place field. As of now the research regarding place neurons is only conducted in animals. More research involving human subjects will open more doors for the future discussion and study.

A place cell under investigation can have only one or very few place fields in a laboratory setting. However in a larger area unlike a laboratory setting it can have more place fields ${ }^{[12]}$. Unlike visual cortex, the clear topography to the pattern of place fields does not exist. Neighboring place cells are likely to have nearby fields just like the place cells at a distance ${ }^{[13]}$. If the ambiance is altered, around 50 percent of the place cells will still have place fields, but these will be in new areas not related to their previous position ${ }^{[14]}$.

A grid cell on the other hand is another type of neuron in the brain that allows an individual or an animal to understand his or its position in space ${ }^{[15-18]}$. The spatial firing fields' arrangements at equal gaps from their neighbors helped generate a hypothesis that these cells can encode a cognitive representation of Euclidean space ${ }^{[19]}$.

\section{Reference}

1. Nobel Prize Neuroscience.

2. Huettel, S.A., Song, A. W., McCarthy, G. Functional Magnetic Resonance Imaging. (2009) Yale J Biol Med 82(4): 233.

3. Moonen, C.T.W., Bandettini, P.A. Functional MRI. (1999) Springer Verlag.

4. Stippich, C. Clinical Functional MRI, Presurgical Functional Neuroimaging. (2007) Springer Verlag.

5. Rizzolatti, G., Craighero, L. The mirror-neuron system. (2004)Annu Rev Neurosci 27: 169-192.

6. Di Pellegrino, G., Fadiga, L., Fogassi, L., et al. Understanding motor events: a neurophysiological study. (1992) Exp Brain Res 91: 176-180. 7. Fogassi, L., Ferrari, P.F., Gesierich, B., et al. Parietal lobe: from action organization to intention understanding. (2005) Science 308(5722): 662-667.

8. Sommerville, J.A., Decety, J. Weaving the fabric of social interaction: Articulating developmental psychology and cognitive neuroscience in the domain of motor cognition. (2006) Psychon Bull Rev 13(2): 179-200.

9. Meltzoff, A.N., Decety, J. What imitation tells us about social cognition: A rapprochement between developmental psychology and cognitive neuroscience. (2003) Philos Trans R Soc Lond B Biol Sci 358(1431): 491-500.

10. Jarosz-Griffiths, H.H., Noble, E., Rushworth, J.V., et al. Amyloid- $\beta$ receptors: the good, the bad and the prion protein. (2015) J Biol Chem. 11. Botsios, S., Manuelidis, L. CJD and Scrapie Require Agent-Associated Nucleic Acids for Infection. (2016) J Cell Biochem.

12. Fenton, A.A., Kao, H.Y., Neymotin, S.A., et al. Unmasking the CA1 ensemble place code by exposures to small and large environments: More place cells and multiple, irregularly arranged, and expanded place fields in the larger space. (2008) J Neurosci 28(44): 11250-11262.

13. O'Keefe, J., Burgess, N., Donnett, J.G., et al. Place cells, navigational accuracy, and the human hippocampus. (1998) Philos Trans R Soc Lond B Biol Sci 353(1373): 1333-1340.

14. Muller, R.U., Kubie, J.L. The effects of changes in the environment on the spatial firing of hippocampal complex-spike cells. (1987) J Neurosci 7(7): 1951-1968.

15. Fyhn, M., Hafting, T., Witter, M.P.,et al. Grid cells in mice. (2008) Hippocampus 18(12): 1230-1238.

16. Yartsev, M.M., Witter, M.P., Ulanovsky, N. Grid cells without theta oscillations in the entorhinal cortex of bats. (2011) Nature 479(7371): 103-107.

17. Killian, N.J., Jutras, M.J., Buffalo, E.A. A map of visual space in the primate entorhinal cortex. (2012) Nature 479: 103-107.

18. Jacobs, J., Weidemann, C.T., Miller, J.F., et al. Direct recordings of grid-like neuronal activity in human spatial navigation. (2013) Nature Neuroscience 16(9): 1188-1190.

19. Hafting, T., Fyhn, M., Molden, S.,et al. Microstructure of a spatial map in the entorhinal cortex. (2005) Nature 436: 801806.
Online ISSN: $2377-1348$

Journal Title: International Journal Neurology and Brain Disorders Journal Short Name: Int J Neurol Brain Disord
Ommega Online Publishers

E-mail: neurology@ommegaonline.com

Website: www.ommegaonline.org 